（85）鉄筇コン 7リート橋脚の動的耐力に及ばす断面形状の影響

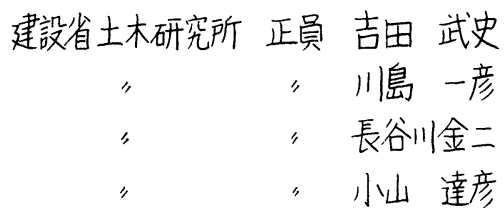

\title{
1.まえがき
}

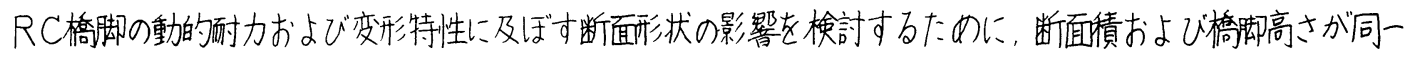
の矩形およじ円形断面供試体(計6体)に対する動的載荷実験を行った結果について報告寸るものである。

\section{2. 実験供試体}

実験に用いた供試体の特性は表1に示すとおりである。断面形状およし配筋は图1に示寸通りであり，断面形

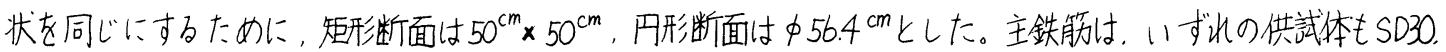

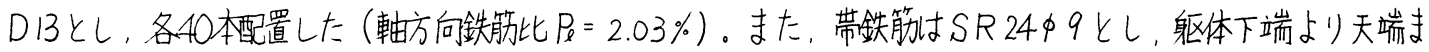

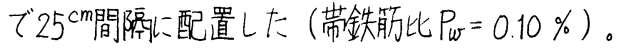
表 1 实験供試体侍性

躯体下端から載荷面中央までの高士(以下躯体 高さと呼ぶけは, 図2に示寸ように矩形, 丹形 ともにそれぞれ2.5 ここで,フーチングの大きさは、フーチング内 で破壤が生じないように十分大きくとった。图

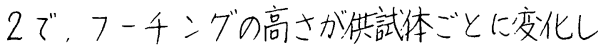
ているが、これは载荷装置の設置位置にあわ世 るため、フーチングの高さで調節した結果であ る。

\section{了。載荷方法}

供試体のフーチング底面を反力床に固定し， 反力壁に設置したアクチュエー夕(最大荷重土 $125^{\text {ton }}$, 最大ストロークェ125 mm )により供試

\begin{tabular}{|c|c|c|c|c|c|c|c|}
\hline \multicolumn{2}{|r|}{ Mode1 No. } & $\mathrm{s}-1$ & $s-2$ & $\mathrm{~s}-3$ & $\mathrm{C}-1$ & $\mathrm{c}-2$ & $\mathrm{C}-3$ \\
\hline \multicolumn{2}{|c|}{ Cross Section $[\mathrm{cm}]$} & $50 \times 50$ & $50 \times 50$ & $50 \times 50$ & 656.4 & $\$ 56.4$ & 656.4 \\
\hline \multicolumn{2}{|c|}{ Covering Depth of Concrete $[\mathrm{cm}]$} & 3.5 & 3.5 & 3.5 & 3.5 & 3.5 & 3.5 \\
\hline \multicolumn{2}{|c|}{ Effective Helght $[\mathrm{cm}]$} & 250 & 175 & 100 & 250 & 175 & 100 \\
\hline \multicolumn{2}{|c|}{ Shear-Span Rat1o } & 5.4 & 3.8 & 2.2 & 4.7 & 3.3 & 1.9 \\
\hline \multirow{3}{*}{$\begin{array}{l}\text { Longitu- } \\
\text { dinal } \\
\text { Reinfor- } \\
\text { c1ng Bar } \\
\text { (Deformed } \\
\text { Bar) }\end{array}$} & \begin{tabular}{|l|} 
Material and \\
D1ameter [mm]
\end{tabular} & SD 30,13 & SD 30,13 & SD 30,13 & SD 30,13 & SD 30,13 & SD 30,13 \\
\hline & Cut-off $[\mathrm{cm}]$ & - & - & - & - & - & - \\
\hline & $\begin{array}{l}\text { Rat10 of Re1nforce- } \\
\text { ment }[\%]\end{array}$ & 2.03 & 2.03 & 2.03 & 2.03 & 2.03 & 2.03 \\
\hline \multirow[t]{2}{*}{ Hoop Tie } & $\begin{array}{l}\text { Material and } \\
\text { Diameter [mm] }\end{array}$ & $\mathrm{SR} 24,9$ & $\mathrm{SR} 24,9$ & SR24,9 & SR24,9 & $\mathrm{SR} 24,9$ & $\mathrm{SR} 24,9$ \\
\hline & $\begin{array}{l}\text { Rat10 of Reinforce- } \\
\text { ment [\%] }\end{array}$ & 0.10 & 0.10 & 0.10 & 0.10 & 0.10 & 0.10 \\
\hline \multirow{3}{*}{ Concrete } & Material & $\begin{array}{l}\text { Portland } \\
\text { Cement }\end{array}$ & \begin{tabular}{|l}
$\begin{array}{l}\text { Portland } \\
\text { Cement }\end{array}$ \\
\end{tabular} & \begin{tabular}{|l|}
$\begin{array}{l}\text { Port1and } \\
\text { Cement }\end{array}$ \\
\end{tabular} & \begin{tabular}{|l|}
$\begin{array}{l}\text { Portland } \\
\text { Cement }\end{array}$ \\
\end{tabular} & \begin{tabular}{|l|}
$\begin{array}{l}\text { Portland } \\
\text { Cement }\end{array}$ \\
\end{tabular} & $\begin{array}{l}\text { Portland } \\
\text { Cement }\end{array}$ \\
\hline & \begin{tabular}{|l|} 
Max Grain S1ze of \\
Aggregate $[\mathrm{mm}]$
\end{tabular} & $1 a_{:}$ & 10 & 10 & 10 & 10 & 10 \\
\hline & $\begin{array}{l}\text { Un1-Axdal Strength } \\
{\left[\mathrm{Kg} / \mathrm{cm}^{2}\right]}\end{array}$ & 319 & 338 & 334 & 406 & 406 & 406 \\
\hline \multirow{3}{*}{$\begin{array}{l}\text { Lateral } \\
\text { Force }\end{array}$} & $\begin{array}{l}\text { D1 rection of Load- } \\
\text { ing }\end{array}$ & $\begin{array}{l}1 \text { Direc- } \\
\text { tion }\end{array}$ & $\begin{array}{l}1 \text { Direc- } \\
\text { tion }\end{array}$ & $\begin{array}{l}1 \text { Direc- } \\
\text { tion }\end{array}$ & $\begin{array}{l}1 \text { D1rec- } \\
\text { tion }\end{array}$ & $\begin{array}{l}1 \text { D1rec- } \\
\text { tion }\end{array}$ & $\begin{array}{l}1 \text { D1rec- } \\
\text { tion }\end{array}$ \\
\hline & $\begin{array}{l}\text { Velocity of Load- } \\
\text { ing }[\mathrm{cm} / \mathrm{sec} .]\end{array}$ & 25.0 & 25.0 & 25.0 & 25.0 & 25.0 & 25.0 \\
\hline & $\begin{array}{l}\text { Number of Loading } \\
\text { for Each Specific } \\
\text { Lateral Displace- } \\
\text { ment }\end{array}$ & 10 & 10 & 10 & 10 & 10 & 10 \\
\hline
\end{tabular}
体頭部煷的荷重を加えた。

載荷履歷は図了に示寸通りとした。すなわ方，供試 体躯体下端の外縁鉄筋の軸ひずみが降伏点に達するま では荷重制御で正負交番載荷し，外䋑鉄筋の軸しずみ が降优後は。: の時に一供試体天端に生じ万变位（以下 降伏变位反yと呼ぶ) を基本として：只整数倍の振幅 で变位制御により荷重を加えた。同一の变位振幅にお ける繰り返し回数は10回とした。

なお，供試体S一3の2dyにおけ武荷時上, 供試体 と反力床を固定しているマンカーボルトの締付不足の

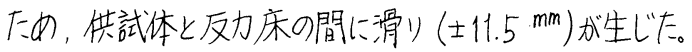

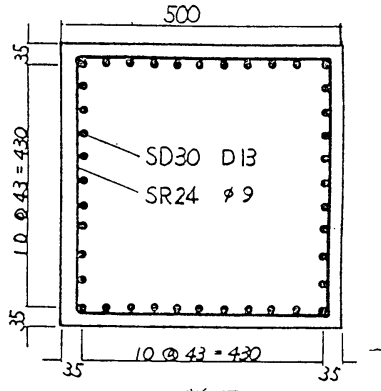

(a) 矩形断面

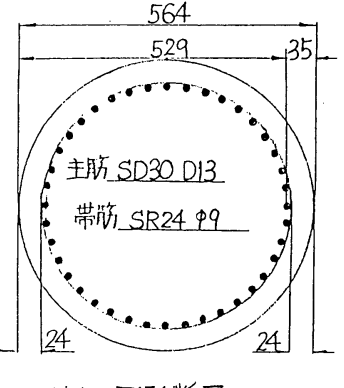

(b) 円形断面

困1実験供試体躯体断面の形状 


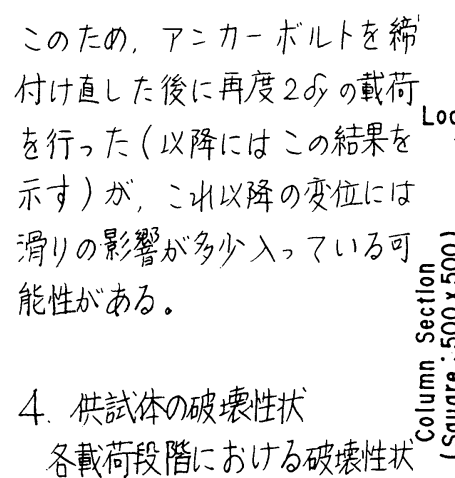
をまとめると表2の通りとなる。 これより以下の事項が指摘され 万。

1)コン7リートのはく離の生

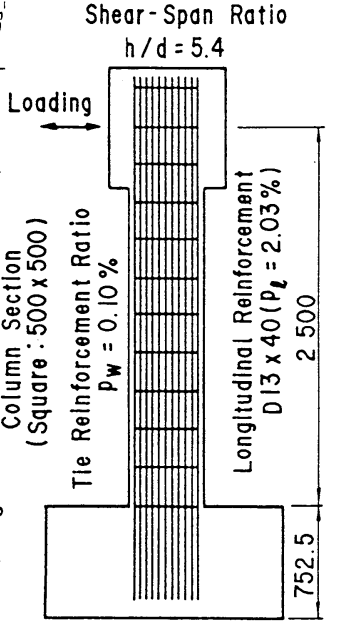

(a) 供試体 $S 1$ $\mathrm{h} / \mathrm{d}=4.7$

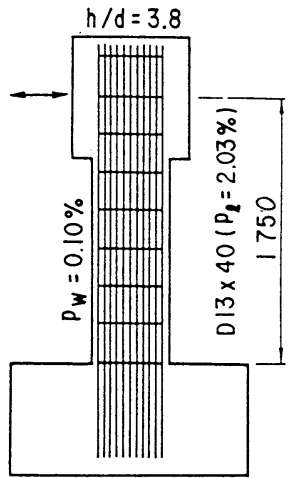

(b) 供試体 S2 $\mathrm{h} / \mathrm{d}=3.3$

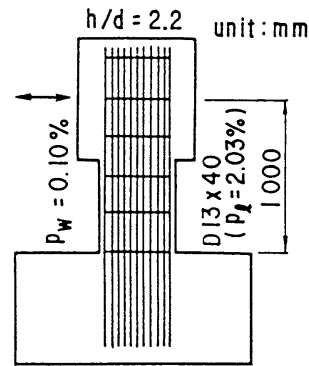

(C) 供試体 S3

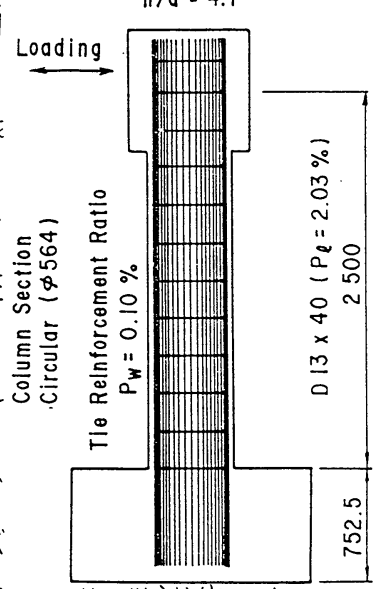

(d) 供試体 C1

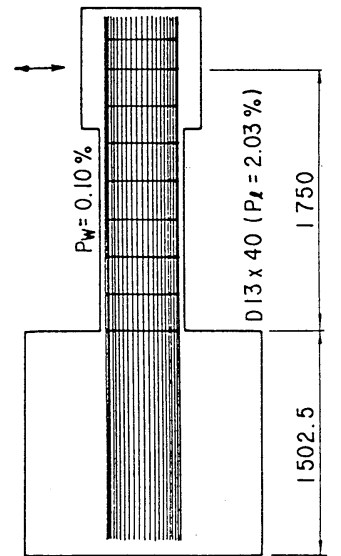

(e) 供試体 C2

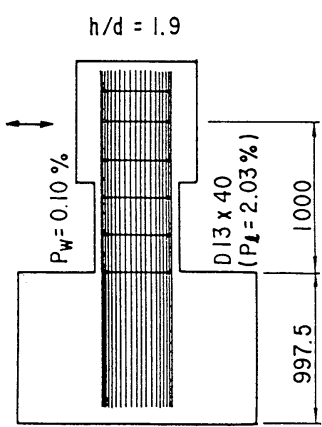

(f) 供試体 C3 $1.0^{\mathrm{m}}$ の場合には，世ん断破壊す る。躯体基部で曲げ破壊する場合には，最初に 南北面(載荷方向に直交す万面のコンクリートが はく離するが，世ん断破壊する場合には、最初 に東西面(載荷方向に平行な面)のコンクリー トがはく離する。

3）身区体基部で曲げ破壊寸る場合には主能の破 断が生じるが、これは円形断面の方が早く発生

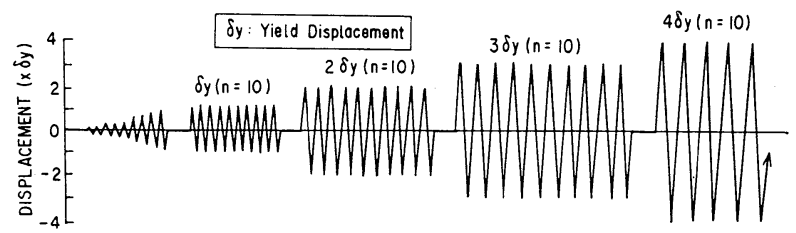

図3 荷重載荷履歷 (变位制御) l, 破断本数毛多い。

4）せん断破壊する場合には、丹形断面，矩形断面ともに、主鉄筋、带鉄筋の破断は最後まで生じなか。た。

\section{5, 荷重〜变位の載荷履歴}

各載荷段階ごとに第1回目の載荷から求めた荷重〜变位履歴曲線の包絡線ちよび履歴减衰定数をそれぞれ図4， 四5に示す。また、表了は耐震性能一覧を示したものである。これより以下の事项が指摘される。

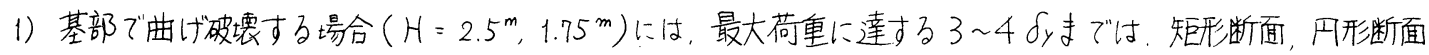

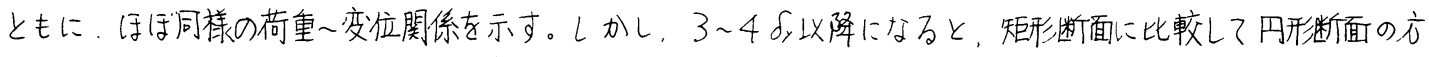


表一2 橋阴模型の破壊性状

\begin{tabular}{|c|c|c|c|c|c|c|}
\hline \multirow[t]{2}{*}{ 变位振幅 } & 矩 & 形断 & 面 & \multicolumn{2}{|r|}{ 形 断 } & \multirow{2}{*}{\begin{tabular}{|l|}
\multicolumn{1}{|}{ 面 } \\
C -3 \\
\end{tabular}} \\
\hline & $S-1$ & $S-2$ & $S-3$ & $c-1$ & $c-2$ & \\
\hline $1 \delta_{y}$ & 変化なし & 変化なし & 变化なし & $\begin{array}{l}\text { 南面に曲げクネッ } \\
\text { ク增加 }\end{array}$ & 变化なし & 变化なし \\
\hline $2 \delta_{y}$ & 变化なし & $\begin{array}{l}\text { 東西面に斜方 } \\
\text { ラック発生 }\end{array}$ & $\begin{array}{l}\text { 鈄めクラック 幅 } \\
\text { 变化 (最大 } 5 \mathrm{~mm} \text { ) }\end{array}$ & \begin{tabular}{|l|} 
斜めクラック \\
発生
\end{tabular} & $\begin{array}{l}\text { 斜めクラッ7 } \\
\text { 発生 }\end{array}$ & $\begin{array}{l}\text { 斜めクラック } \\
\text { 增加 }\end{array}$ \\
\hline $3 \delta y$ & $\begin{array}{l}\text { 西面䔑仡 } \\
\text { ラック増加 }\end{array}$ & $\begin{array}{l}\text { 東西面に斜めク } \\
\text { ラッフ増加 }\end{array}$ & $\begin{array}{l}\text { 東西面コンクリー } \\
\text { 卜はく離開始 }\end{array}$ & $\begin{array}{l}\text { 北面コンクリー } \\
\text { トはく離 }\end{array}$ & $\begin{array}{l}\text { 验めクラック } \\
\text { 增加 }\end{array}$ & 变化なし \\
\hline $4 \delta_{y}$ & $\begin{array}{l}\text { 東西面に斜め7 } \\
\text { ラック堌加 } \\
\text { 南北面のコンクリ } \\
\text { - -上く離開始 }\end{array}$ & $\begin{array}{l}\text { 南北面のコン } \\
\text { リートはく離 }\end{array}$ & $\begin{array}{l}\text { 瑓西面コンクリ } \\
\text { ートはく離 }\end{array}$ & $\begin{array}{l}\text { 南面コンクリー } \\
\text { トはく離 }\end{array}$ & $\begin{array}{l}\text { 南北面のコンク } \\
\text { リートはく離 }\end{array}$ & $\begin{array}{l}\text { 東西面のコンク } \\
\text { リートはく離 }\end{array}$ \\
\hline $5 \delta y$ & $\begin{array}{l}\text { 南北面のコン7 } \\
\text { リート完全には } \\
\text { く離 }\end{array}$ & $\begin{array}{l}\text { 南北面のコンク } \\
\text { リートはくく離迫 } \\
\text { 行. 東西面のコ } \\
\text { ンクリートはく離 }\end{array}$ & $\begin{array}{l}\text { 東西面のコンク } \\
\text { 将ートはく離進 } \\
\text { 行 }\end{array}$ & $\begin{array}{l}\text { ほぼ全周にわた } \\
\text { リコンフリートは } \\
\text { く離 } \\
\text { 主䐕5本切断 } \\
\end{array}$ & $\begin{array}{l}\text { 尸ンク.リートは } \\
\text { くリ進行 }\end{array}$ & $\begin{array}{l}\text { 東西面のコンク } \\
\text { リートはく離進 } \\
\text { 行. 南北面のコ } \\
\text { ンクリートくく離 }\end{array}$ \\
\hline $6 \delta y$ & 住筋1本切断 & 变化なし & $\begin{array}{l}\text { 南面のコンクリー } \\
\text { 卜はく離. }\end{array}$ & 主筋9本切断 & 主筋3本切断 & $\begin{array}{l}\text { コンクリートはく } \\
\text { 離璡行 }\end{array}$ \\
\hline $7 \delta_{y}$ & $\begin{array}{l}\text { 席鉄筋はずれる。 } \\
\text { 住筋了本切断 }\end{array}$ & 主筋6本切断 & $\begin{array}{l}\text { 唐西面のコンクリ } \\
\text { 一ト半はく離 }\end{array}$ & 主筋8本切断 & 主筋15本切断 & $\begin{array}{l}\text { コンクリートはく } \\
\text { 離進行 }\end{array}$ \\
\hline $8 \delta_{y}$ & 主筋1本切断 & 主筋 6本切断 & - & 主筋3本切断 & 主筋6本切断 & - \\
\hline \multirow[b]{2}{*}{ 備考 } & $\delta_{y}=13^{\mathrm{mm}}$ & $\delta_{y}=7.5^{\mathrm{mm}}$ & $\delta_{y}=4.9^{\mathrm{mm}}$ & $\delta_{y}=13^{\mathrm{mm}}$ & $\delta_{y}=7.5^{\mathrm{mm}}$ & $\delta_{y}=4.9^{\mathrm{mm}}$ \\
\hline & \multicolumn{3}{|c|}{ 南 } & \multicolumn{3}{|c|}{ 南 } \\
\hline
\end{tabular}

が同一变位に対する荷重が低下寸るようになる。:れは表2に示したように，円形断面の方が主鉄㬳の破断の進 行が早いことに対応していると考之られる。履歴减衰定数についても, 最大荷重までは断面形状の影輩はほとん どみられない。最大荷重後は，矩形断面の方が履歴减衰定数が早く低下する倾向にある。

2) 世ん断破壞する場合 $(H=1.0$ m)には,十側飞一侧の载荷によ, 子断面形状の影響の仕方が異なっている。

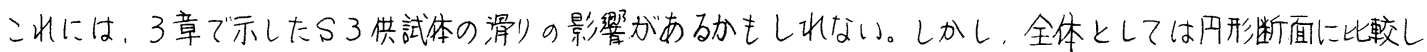
て矩形断面の方が荷重の低下が著しい。二れは，矩形断面の方が斜めクラッフの進展が早いことに対応している。 履歴减衰定数の变化に関してもこれと同样のことが言之る。

3）以上の結果を評価するに際しては表1に示したように、コン7リートの圧縮強度は円形䉼面（ の市が短形断面 $\left(\sigma=319 \sim 338 \mathrm{~kg} / \mathrm{cm}^{2}\right)$ よりも20\%程度大きいことに留意しなければるらない。

\section{7. 結論}

躯体高さ，断面積，粙方向鉄趿比，带鉄胼比が同じであれば，断面形状（矩形，円形）に関して以下の事項が 指摘士心子。

1)基部が曲げ破俵寸る場合には最大耐力に達するまでは，断面形状の差はあまり認められないが、最大耐力以 
降は、矩形断面の方が円形断面よりも耐力の低 下がやメ遅い。

2) せん断破壊才万場合は，最大耐力に達した 後の耐力の低下の度合いは，矩开断面の方が円 形断面よりも大きい。また，最大耐力も矩形断 面の方が円形断面のりも小さい。しかしながら， 後者については、コンクリートの圧縮強度が、 矩形断面の方が円形断面よりも2 0 \% 程度小さい ことが影響していると考えられる。

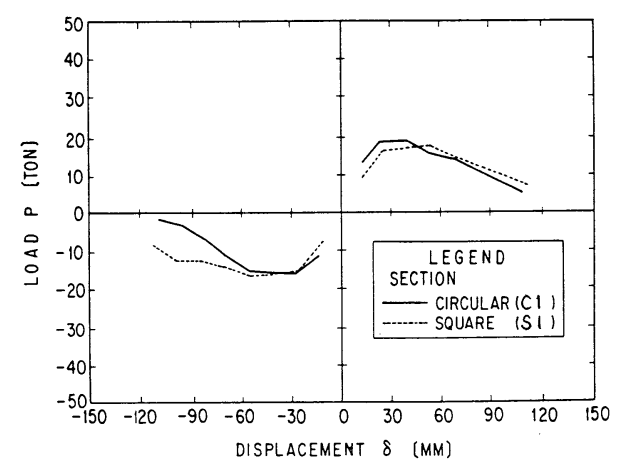

(a) 躯体高 $\pm 2.5^{\mathrm{m}}$ の場合

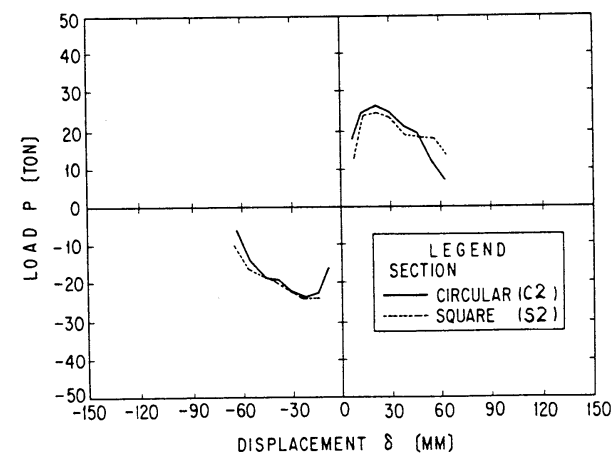

(b) 躯体高さ1.75 m の場合

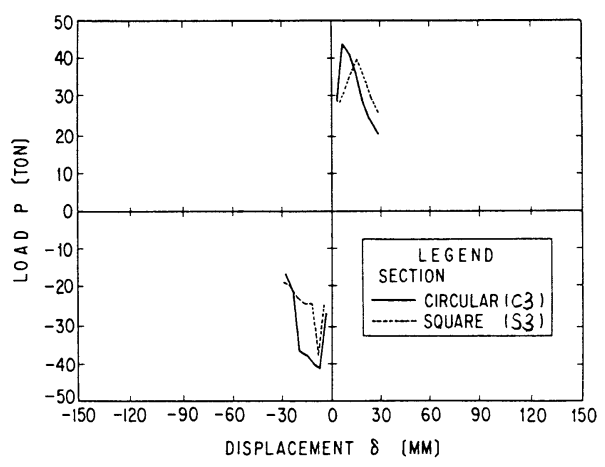

(c) 躯体高士 $1.0 \mathrm{~m}$ 日埸合

図4荷重，变位包絡線
表了耐震性能の一覽表

\begin{tabular}{|c|c|c|c|c|c|c|}
\hline Model No. & $S-1$ & $s-2$ & $\mathrm{~s}-3$ & $\mathrm{C}-1$ & $\mathrm{C}-2$ & $\mathrm{C}-3$ \\
\hline Shape of Cross Section & \multicolumn{3}{|c|}{ Square } & \multicolumn{3}{|c|}{ Circle } \\
\hline Pier Height $[\mathrm{cm}]$ & 250 & 175 & 100 & 250 & 175 & 100 \\
\hline $\begin{array}{l}\text { Yield Strength } \\
\operatorname{Py}[t]\end{array}$ & 13.9 & 21.7 & 37.8 & 13.4 & 20.4 & 37.0 \\
\hline $\begin{array}{c}\text { Maximum Strength } \\
\mathrm{Pu}[\mathrm{t}]\end{array}$ & 17.0 & 23.8 & 41.1 & 17.3 & 25.2 & 42.8 \\
\hline$\frac{\mathrm{Pu}}{\mathrm{Py}}$ & 1.22 & 1.1 & 1.09 & 1.29 & 1.24 & 1.16 \\
\hline $\begin{array}{l}\text { Yield Displacement } \\
\text { oy }[\mathrm{mm}]\end{array}$ & 15.4 & 10.1 & 6.0 & 15.2 & 10.0 & 4.9 \\
\hline $\begin{array}{c}\text { U1timate Displacement } \\
\delta \mathrm{u}[\mathrm{mm}]\end{array}$ & 74.1 & 33.1 & 11.2 & 63.8 & 43.5 & 17.0 \\
\hline$\frac{\delta u}{\delta y}$ & 4.81 & 3.28 & 1.87 & 4.2 & 4.4 & 3.5 \\
\hline
\end{tabular}
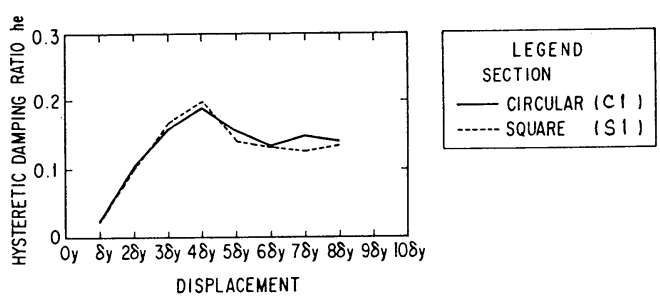

(a) 躯体高士2.5 m の埸合

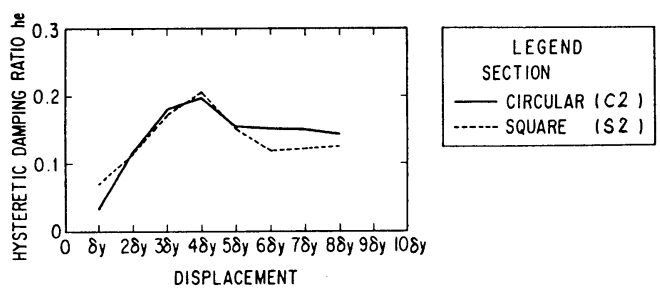

(b) 躯体高士 $1.75^{\mathrm{m}}$ の場合

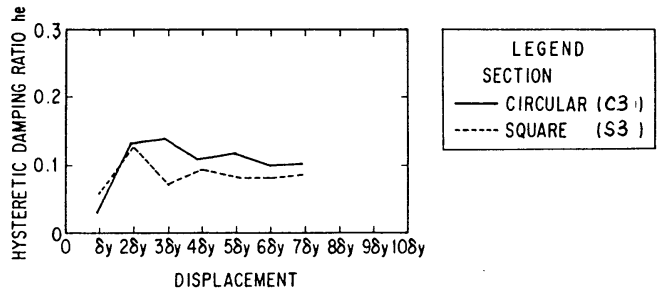

(C) 躯体高士 $1.0 \mathrm{~m}$ の場合

四5 履歴减衰定数he～变位振幅の関係 